\title{
KAJIAN YURIDIS PERLINDUNGAN HUKUM TERTANGGUNG PADA PERJANJIAN ASURANSI KENDARAAN BERMOTOR DI PT. ASURANSI RAMAYANA TBK. JAKARTA
}

\author{
Novianta Budi Surana \\ Magister Hukum Fakultas Hukum Universitas Jenderal Soedirman
}

\begin{abstract}
The legal protection for the insured in an insurance agreement with PT Asuransi Ramayana Tbk exists while being observed generally by insurance law for the fulfillment of rights and obligations of both the insured and the insurer. In case of force majeur (unsure occurance) which causes loss; then based on Indonesian Standard Insurance Policy for Motor Vehicle Chapter 1 Article 1 and Article 2, the insured deserves to get the indemnity due to theft, and also get the solution for the dispute through a mediator under Article 54 Chapter XI 40 of 2014 concerning insurance about the protection of Insurance Policy holders, the Insured or the participant.

The refusal of legal validity of the claim by PT. Asuransi Ramayana Tbk is not appropriate and does not have any correlation with the case of theft occurred because in Mr. Mery Sam Arvianto's case, the insurance agreement with the insurance policy number 18.0212.14.001512 must covers All Risk / Comprehensive ( collateral damage to a part or the whole car because of falling objects, fire, collision, traffic accidents, theft or collision), and the insured should receive compensation, based on Chapter 1 Article 1 paragraph 1.3 Indonesian Standard Policy for motor vehicle insurance governing the guarantee, including guarantee from theft.
\end{abstract}

Key Words: The legal protection for the insured in an insurance agreement.

ABSTRAK

Perlindungan hukum tertanggung dalam perjanjian asuransi kendaraan bermotor PT. Asuransi Ramayana Tbk ditinjau dari hukum asuransi secara umum yakni terpenuhinya Hak dan kewajiban dari tertanggung dan penanggung. Bilamana terjadi evenemen (peristiwa tidak pasti) yang menimbulkan kerugian, maka berdasarkan Polis Standar Asuransi Kendaraan Bermotor Indonesia BAB 1 Pasal 1 dan Pasal 2, tertanggung berhak mendapatkan ganti rugi karena pencurian, begitu juga berhak mendapatkan penyelesaian sengketa melalui lembaga mediasi berdasarkan Pasal 54 BAB XI UU No 40/2014 tentang Perasuransian yaitu tentang Perlindungan Pemegang Polis, Tertanggung, atau Peserta.

Berlakunya hukum pengajuan klaim tertanggung ditolak PT.Asuransi Ramayana Tbk adalah tidak tepat dan tidak berkorelasi dengan kasus pencurian yang terjadi sebab dalam kasus yang dialami Bapak Mery Sam Arvianto, dalam perjanjian asuransi dengan nomor polis 18.0212.14.001512 maka tertanggung menurut klausula All Risk/ Comprehensive ( jaminan kerusakan sebagian atau keseluruhan mobil karena kejatuhan benda, kebakaran, tabrakan, kecelakaan lalu lintas, pencurian, atau benturan), seharusnya mendapatkan ganti rugi, hal ini berdasarkan BAB 1 Pasal 1 angka 1.3 Polis standar asuransi kendaraan bermotor Indonesia yang mengatur tentang jaminan, diantaranya tentang pencurian.

Kata kunci: Perlindungan hukum tertanggung dalam perjanjian asuransi

\section{PENDAHULUAN}

Perkembangan teknologi di bidang industri transportasi baik darat, laut maupun udara berkembang sangat pesat. Negara maju maupun berkembang saat ini telah menggunakan hasil-hasil produksi teknologi yang tinggi di bidang alat transportasi, meskipun yang menikmati hasil produksi tersebut baru sebagian golongan masyarakat saja. Masyarakat yang akan bergabung atau menjadi nasabah perusahaan asuransi perlu mengetahui apa kriteria, pedoman yang layak dipertim- 
bangkan ketika akan memilih suatu asuransi. Dalam hubungan ini, beberapa kriteria atau pedoman tersebut dapat dikemukakan antara lain: (1) Perusahaan asuransi hanya menjual program berdasarkan kemampuan nasabah. Jika kemampuan konsumen tak memenuhi implikasinya pertang-gungan putus di tengah jalan; (2) Produk yang dijual sesuai dengan kebutuhan, artinya kebutuhan nasabah lebih diutamakan; (3) Nasabah yang membeli polis harus sehat; (4) Komitmen nasabah dalam membeli produk yang dipilih, setidaknya ada tatap muka dan tidak hanya melalui telepon; (5) Kondisi keuangan suatu perusahaan asuransi. Setidaknya memilih asuransi yang sudah terpercaya dan bonafit. ${ }^{1}$

Asuransi dan Pertanggungan, Kedua istilah itu berasal dari bahasa Belanda yaitu verzekering dan assurantie. Dalam bahasa Inggris insurance oleh Soekardono diterjemahkan sebagai verzekering adalah pertanggungan, Istilah pertanggungan banyak dipakai dalam IImu Pengetahuan dan literatur sedangkan Istilah asuransi dipakai pada nama perjanjian atau nama perusahaan. Insurance (digunakan untuk asuransi jiwa/jumlah sedangkan Assurance (digunakan untuk asuransi kerugian), dengan demikian maka Pertanggungan dan asuransi mempunyai arti yang sama. $^{2}$

Perjanjian asuransi atau pertanggungan merupakan suatu perjanjian yang mempunyai sifat khusus dan unik, sehingga perjanjian ini

\footnotetext{
DE.Ernawati. 2009 Penerapan Asas-asas Hukum Asuransi dalam Perjanjian Asuransi Kendaraan Bermotor di PT. Asuransi Raksa Pratikara di Wilayah Surakarta. Semarang, Tesis Fakultas Hukum, Universitas Diponegoro. Hal.13

2 Zainudin, 2013. Hukum Pertanggungan atau Asuransi. (On-line), http://muhyusuf0464.blogspot.com/2013/11/yu.html diakses 12 Desember 2014
}

mempunyai karakteristik tertentu yang khas dibandingkan dengan perjanjian lain. Secara umum perjanjian asuransi harus memenuhi asas-asas tertentu yang mewujudkan sifat atau ciri khusus dari perjanjian asuransi itu sendiri. ${ }^{3}$

Perjanjian asuransi atau pertanggungan secara khusus diatur dalam Kitab UndangUndang Hukum Dagang (KUHD). Perjanjian ini diklasifikasikan sebagai suatu perjanjian khusus dan yang tunduk pada ketentuanketentuan khusus pula. ${ }^{4}$

Asas-asas perjanjian asuransi yang diatur dalam KUHD hampir seluruhnya merupakan asas-asas yang berlaku bagi asuransi kerugian pada umumnya. Asas-asas termaksud pada umumnya memberikan pengamanan terhadap kepentingankepentingan yang berkaitan dengan pemilikan dan kebendaan.

Adapun asuransi ini dapat digolongkan menjadi dua yaitu asuransi Kerugian dan Asuransi Jiwa. Menurut Pasal 246 yuncto Pasal 247 KUHD dikenal adanya asuransi kerugian dan asuransi jiwa. Menurut ketentuan Pasal 1 angka 15 Undang-undang Nomor 40 Tahun 2014 Tentang Perasuransian (selanjutnya disingkat UU No 40/2014), yang dimaksud Perusahaan Asuransi adalah perusahaan asuransi umum dan perusahaan asuransi jiwa

Menurut Pasal 1 angka 1 UU No 40/2014. Asuransi adalah perjanjian antara dua pihak, yaitu perusahaan asuransi dan pemegang polis, yang menjadi dasar bagi penerimaan premi oleh perusahaan asuransi sebagai imbalan untuk: (1) memberikan peng-

\footnotetext{
Sri Rejeki Hartono, 2001, Hukum Asuransi dan Perusahaan Asuransi, Jakarta, Sinar Grafika, Hal.89 4 Ibid, Hal.90
} 
gantian kepada tertanggung atau pemegang polis karena kerugian, kerusakan, biaya yang timbul, kehilangan keuntungan, atau tanggung jawab hukum kepada pihak ketiga yang mungkin diderita tertanggung atau pemegang polis karena terjadinya suatu peristiwa yang tidak pasti; atau (2) memberikan pembayaran yang didasarkan pada meninggalnya tertanggung atau pembayaran yang didasarkan pada hidupnya tertanggung dengan manfaat yang besarnya telah ditetapkan dan/atau didasarkan pada hasil pengelolaan dana.

Di dalam Asuransi terdapat adanya Perjanjian Asuransi, adapun Kitab UndangUndang Hukum Perdata (KUH Perdata) menyatakan secara spesifik adanya "kesepakatan" yang merupakan suatu syarat yang harus dipenuhi untuk sahnya perjanjian. Pada saat ini masyarakat menuntut diberlakukannya perjanjian standar, untuk selanjutnya standar kontrak dapat dikatakan sama dengan perjanjian baku.

Salah satu jenis asuransi diantaranya adalah asuransi kendaraan bermotor, dalam asuransi ini disebutkan adanya perjanjian, dimana seorang penanggung mengikatkan diri kepada seorang tertanggung, dalam hal ini penanggung disebut juga sebagai perusahaan asuransi dan tertanggung disebut juga dengan pemegang polis, dengan menerima suatu premi, untuk memberikan penggantian kepadanya karena suatu kerugian, kerusakan atau kehilangan keuntungan yang diharapkan, yang mungkin akan dideritanya karena suatu peristiwa yang tidak tertentu.

Pengajuan klaim seringkali menjadi masalah bagi tertanggung karena ditolak perusahaan asuransi dengan alasan tidak memenuhi unsur yang diperjanjikan dalam polis.
Sebagaimana contoh kasus pencurian mobil xenia milik Bapak Mery Sam Arvianto yang pada waktu kejadian sedang dipinjam oleh Bapak Joko (pihak ketiga). Mobil tersebut telah diasuransikan di PT. Asuransi Ramayana Tbk. dengan nomor polis 18.0212.14.001512 dimana perjanjian asuransi tersebut menggunakan klausula All Risk/Comprehensive yang isinya menyatakan jaminan kerusakan sebagian atau keseluruhan mobil karena kejatuhan benda, kebakaran, tabrakan, kecelakaan lalu lintas, pencurian, atau benturan. Ketika terjadi peristiwa kerugian yang dipertanggungkan yaitu adanya pencurian terhadap mobil yang diasuransikan dimana mobil tersebut digunakan oleh pihak ketiga (bukan tertanggung sendiri) dan ternyata yang bersangkutan tidak memiliki SIM dan ketika klaim diajukan oleh tertanggung, Penanggung (pihak asuransi) menolak dengan mendasarkan kepada Polis Standard Asuransi Kendaraan Bermotor Indonesia Pasal 3 Angka 4.2 yaitu pada saat terjadi kerugian atau kerusakan, kendaraan bermotor dikemudikan oleh seseorang yang tidak memiliki Surat Izin Mengemudi (SIM) sesuai dengan peraturan perundang-undangan yang berlaku. Dengan penolakan tersebut tertanggung merasa dirugikan karena ia merasa bahwa kerugian yang dialami berupa pencurian tersebut akan ditanggung oleh penanggung sesuai dengan klausula All Risk.

\section{METODE PENELITIAN}

Penelitian ini menggunakan pendekatan yuridis-normatif, menurut Soerjono Soekanto dan Sri Mamuji, penelitian hukum normatif adalah penelitian hukum yang dilakukan dengan cara meneliti bahan pustaka atau data 
sekunder belaka. Penelitian ini mencakup penelitian terhadap asas-asas hukum, penelitian terhadap sistematik hukum, penelitian terhadap singkronisasi vertikal dan horizontal, perbandingan hukum, sejarah hukum dan inventarisasi hukum positif. ${ }^{5}$ Spesifikasi penelitian ini adalah deskriptif, yaitu suatu penelitian yang menggambarkan keadaan obyek yang akan ditelití. Penelitian ini menggunakan metode analisa normatif. Analisa normatif diarahkan pada norma hukum, teori hukum, asas hukum, maupun pengertian hukum yang terkait dengan permasalahan yang ada dalam penelitian ini. Analisis data dilakukan secara kualitatif, yaitu analisa berupa kalimat dan uraian yang digunakan untuk menganalisa data yang tidak dapat diukur dengan angka.

\section{PEMBAHASAN}

Perlindungan Hukum tertanggung dalam perjanjian asuransi kendaraan bermotor PT. Asuransi Ramayana Tbk ditinjau dari hukum asuransi secara umum

Menurut Fitzgerald, Teori perlindungan hukum Salmond bahwa hukum bertujuan mengintegrasikan dam mengkoordinasikan berbagai kepentingan dalam masyarakat karena dalam suatu lalulintas kepentingan, perlindungan terhadap kepentingan tertentu dapat dilakukan dengan cara membatasi berbagai kepentingan di lain pihak. ${ }^{7}$

Philipus Hadjon mengartikan perlindungan hukum sebagai berikut:

\footnotetext{
Soerjono Soekanto dan Sri Mamudji, 2004, Penelitian Hukum Normatif, Suatu Tinjaun Singkat, Jakarta, Raja Grafindo Persada, Hal. 13-14.

6 Bambang Sunggono, 2006, Metode Penelitian Hukum, Jakarta, PT Raja Grafindo Persada, Hal. 35.

7 Satijipto Raharjo, 2000, IImu Hukum, Bandung, PT. Citra Aditya Bakti, Hal. 53.
}

Perlindungan hukum merupakan perlindungan harkat, martabat dan pengakuan terhadap hak asasi manusia yang dimiliki oleh subyek hukum dalam negara hukum dengan berdasarkan pada ketentuan hukum yang berlaku di negara tersebut guna mencegah terjadinya kesewenang-wenangan. Perlindungan hukum itu pada umumnya berbentuk suatu peraturan tertulis, sehingga sifatnya lebih mengikat dan akan mengakibatkan adanya sanksi yang harus dijatuhkan kepada pihak yang melanggarnya. ${ }^{8}$

Philipus M. Hadjon, juga membedakan macam perlindungan hukum, yaitu: (1) Perlindungan hukum yang preventif yang bertujuan untuk mencegah terjadinya permasalahan atau sengketa; (2) Perlindungan hukum yang represif yang bertujuan untuk menyelesaikan permasalahan atau sengketa yang timbul. ${ }^{9}$

Sulistyandari juga menyatakan bahwa perlindungan hukum itu berkaitan bagaimana hukum memberikan keadilan yaitu memberikan atau mengatur hak dan kewajiban terhadap subyek hukum, selain itu juga berkaitan bagaimana hukum memberikan keadilan terhadap subyek hukum yang dilanggar haknya untuk mempertahankan haknya tersebut. 10 Dengan demikian wujud atau bentuk perlindungan hukum berupa hak dan kewajiban dari subyek hukum yang dalam hal ini adalah hak tertanggung yang merupakan kewajiban tertanggung, yang dibedakan kedalam perlindungan hukum kontraktual yaitu berupa

Philipus M. Hadjon, 1987, Perlindungan Hukum bagi Rakyat Indonesia, Surabaya, Bina IImu, hal 205

9 lbid., hal 117

10 Sulistyandari, 2012, Hukum Perbankan (Perlindungan Hukum Terhadap Nasabah Penyimpan Melalui Pengawasan Perbankan di Indonesia), Sidoarjo ,Laras, Hal. 283 
perjanjian dan non kontraktual yaitu berupa peraturan perundang-undangan, peraturan tidak tertulis dan putusan pengadilan.

Perlindungan hukum merupakan gambaran dari bekerjanya fungsi hukum untuk mewujudkan tujuan-tujuan hukum, yakni keadilan, kemanfaatan dan kepastian hukum. Perlindungan hukum adalah suatu perlindungan yang diberikan kepada subyek hukum sesuai dengan aturan hukum, baik itu yang bersifat preventif maupun dalam bentuk yang bersifat represif, baik yang secara tertulis maupun tidak tertulis dalam rangka menegakkan peraturan hukum.

Usaha asuransi merupakan suatu mekanisme yang memberikan perlindungan pada tertanggung apabila terjadi risiko di masa mendatang. Apabila risiko tersebut benarbenar terjadi, pihak tertanggung akan mendapatkan ganti rugi sebesar nilai yang diperjanjikan antara penanggung dan tertanggung. Mekanisme perlindungan ini sangat dibutuhkan dalam dunia bisnis yang penuh dengan risiko. Secara rasional, para pelaku bisnis akan mempertimbangkan untuk mengurangi risiko yang dihadapi. Adapun Peraturan yang memberikan perlindungan hukum di Republik Indonesia ini terdapat dalam Burgelijk Wetboek (Kitab Undang-Undang Hukum Perdata/ KUH Perdata), disitu terdapat 11 ketentuan-ketentuan yang bertujuan memberi perlindungan, seperti tersebar dalam beberapa pasal buku III, bab V, bagian 2 yang dimulai dari Pasal 1365 KUH Perdata. Dalam KUHD, misalnya tentang pihak ketiga yang harus dilindungi, tentang perlindungan penumpang/ barang muatan pada hukum maritim, ketentuan-ketentuan mengenai perantara, asuransi, surat berharga, kepailitan, dan sebagainya.
Dalam Kitab Undang-undang Hukum Pidana (KUH Pidana), misalnya tentang pemalsuan, penipuan, pemalsuan merek, persaingan curang, dan sebagainya. Demikian pula dalam UU No 40/2014 tentang Perasuransian, BAB XI tentang Perlindungan Pemegang Polis, Tertanggung, atau Peserta. Pada Pasal 53 mengatur tentang perlindungan hukum yaitu : (1) Perusahaan Asuransi dan Perusahaan Asuransi Syariah wajib menjadi peserta program penjaminan polis; (2) Penyelenggaraan program penjaminan polis sebagaimana dimaksud pada ayat (1) diatur dengan undang-undang; (3) Pada saat program penjaminan polis berlaku berdasarkan undangundang sebagaimana dimaksud pada ayat (2), ketentuan mengenai Dana Jaminan sebagaimana dimaksud dalam Pasal 8 ayat (2) huruf $d$ dan Pasal 20 dinyatakan tidak berlaku untuk Perusahaan Asuransi dan Perusahaan Asuransi Syariah; (3) Undang-undang sebagaimana dimaksud pada ayat (2) dibentuk paling lama 3 (tiga) tahun sejak Undang-Undang ini diundangkan.

\section{Pada Pasal 54 mengatur tentang perlin- dungan hukum yaitu:}

1. Perusahaan Asuransi, Perusahaan Asuransi Syariah, perusahaan reasuransi, dan perusahaan reasuransi syariah wajib menjadi anggota lembaga mediasi yang berfungsi melakukan penyelesaian sengketa antara Perusahaan Asuransi, Perusahaan Asuransi Syariah, perusahaan reasuransi, atau perusahaan reasuransi syariah dan Pemegang Polis, Tertanggung, Peserta, atau pihak lain yang berhak memperoleh manfaat asuransi. 
2. Lembaga mediasi sebagaimana dimaksud pada ayat (1) bersifat independen dan imparsial

3. Lembaga mediasi sebagaimana dimaksud pada ayat (1) harus mendapat persetujuan tertulis dari Otoritas Jasa Keuangan.

4. Kesepakatan mediasi bersifat final dan mengikat bagi para Pihak.

5. Ketentuan lebih lanjut mengenai lembaga mediasi sebagaimana dimaksud pada ayat (1), ayat (2), ayat (3), dan ayat (4) diatur dalam Peraturan Otoritas Jasa Keuangan

Apabila suatu kerugian terjadi sebagai akibat dari suatu peristiwa yang tidak tertentu yang tidak diperjanjikan, maka tentu saja penanggung harus memenuhi kewajibannya untuk memberi ganti kerugian. Meskipun demikian tidak setiap kerugian dan setiap adanya peristiwa selalu berakhir dengan pemenuhan kewajiban penanggung terhadap tertanggung, melainkan harus dalam suatu rangkaian peristiwa yang mempunyai hubungan sebab akibat. Perusahaan asuransi sebagai penanggung dengan tegas memberikan kriteria dan batasan luasnya proteksi atau jaminan yang diberikannya kepada tertanggung. Kriteria dan batasan tersebut dicantumkan di dalam polis, sesuai dengan jenis asuransi yang bersangkutan. Sehingga setiap polis tercantum jenis peristiwa apa saja yang menjadi tanggung jawab penanggung. jadi apabila terjadi kerugian yang disebabkan karena peristiwa-peristiwa yang diperjanjikan itulah penanggung akan membayar ganti kerugian.

Kewajiban Pertanggungan dan risiko yang dijamin/ dilindungi oleh PT Asuransi Ramayana Tbk adalah risiko-risiko yang dijaminan dalam Polis Standar Asuransi
Kendaraan Bermotor Indonesia (PSAKBI) diantara:

1. Jaminan terhadap kendaraan bermotor (Pasal 1)

Menjamin Kerugian dan atau kerusakan pada Kendaraan Bermotor yang secara langsung disebabkan oleh :

a. tabrakan, benturan, terbalik, tergelincir, atau terperosok

b. perbuatan jahat

c. pencurian termasuk pencurian dengan kekerasan

d. kebakaran

e. kerugian atau kerusakan selama Kendaraan Bermotor berada di atas kapal feri untuk penyeberangan

2. Jaminan tanggung jawab hukum terhadap pihak ketiga (Pasal 2)

Menjamin Kerugian dan atau kerusakan pada Kendaraan Bermotor yang secara langsung disebabkan oleh :

a. kerusakan atas harta benda pihak ketiga

b. biaya pengobatan, cidera badan dan kematian pihak ketiga

c. biaya perkara atau bantuan hukum

3. Perluasan jaminan

Menjamin Kerugian dan atau kerusakan pada Kendaraan Bermotor yang secara langsung disebabkan oleh :

a. kerusuhan, pemogokan, dan huru hara

b. gempa bumi, letusan gunung berapi dan tsunami

c. angin topan, badai, hujan es, banjir dan tanah longsor

d. tanggung jawab hukum terhadap penumpang

e. kecelakaan diri pengemudi dan penumpang

f. dan fitur-fitur jaminan lainnya, 
Pilihan Paket Jaminan Risiko asuransi kendaraan bermotor yang dijamin/dilindungi oleh PT Asuransi Ramayana Tbk adalah risikorisiko yang dijaminan dalam Polis Standar Asuransi Kendaraan Bermotor Indonesia (PSAKBI) diantara:

1. Comprehensive: memberikan ganti rugi terhadap kerusakan total dan kerusakan sebagian

2. Total Loss Only (TLO): memberikan ganti rugi terhadap kerusakan total saja atau jika biaya perbaikan lebih dari $75 \%$ dari harga kendaraan atau kendaraan hilang karena pencurian atau perampokan.

3. Third Party Liability (TPL): memberikan ganti rugi atas tanggung jawab hukum terhadap pihak ketiga.

Kewajiban utama penanggung dalam perjanjian asuransi sebenarnya adalah memberi ganti kerugian sebagai suatu bentuk perlindungan atas sesuatu yang diasuransikan. Meskipun demikian kewajiban memberi ganti rugi itu merupakan suatu kewajiban bersyarat atas terjadi atau tidak terjadinya suatu peristiwa yang diperjanjikan yang mengakibatkan timbulnya suatu kerugian. Artinya, pelaksanaan kewajiban penanggung itu masih tergantung pada terjadi atau tidak terjadinya peristiwa yang telah diperjanjikan oleh para pihak sebelumnya.

Berlakunya hukum tertanggung dalam perjanjian asuransi dengan klausula All Risk/Comprehensive dihubungkan dengan kasus klaim tertanggung dengan nomor polis 18.0212.14.001512 atas kendaraan yang diasuransikan di PT. Asuransi Ramayana Tbk
Hukum yang mengatur dalam pengajuan klaim seringkali menjadi masalah bagi tertanggung karena ditolak perusahaan asuransi dengan alasan tidak memenuhi unsur yang diperjanjikan dalam polis. Kasus yang dialami Bapak Mery Sam Arvianto yang membeli mobil merk Daihatsu type Xenia 1.3 M/T tahun 2014 yang kemudian diikat dengan perjanjian pembiayaan mobil dengan PT Astra Sedaya Finance Jakarta, kemudian mobil tersebut juga diasuransikan di PT.Asuransi Ramayana Tbk dengan nomor polis 18.0212.14.001512 klausula All Risk/ Comprehensive ( jaminan kerusakan sebagian atau keseluruhan mobil karena kejatuhan benda, kebakaran, tabrakan, kecelakaan lalu lintas, pencurian, atau benturan). Dengan jangka waktu tanggal 13 mei 2014 sampai 12 mei 2019. Pada hari kamis tanggal 22 januari 2015 mobil tersebut sedang dipinjam oleh Bapak Haryono dan mengalami musibah hilang karena dicuri pada saat diparkir. Pencurian tersebut segera dilaporkan ke Polsek Jagakarsa Jakarta. Selanjutnya Bapak Mery Sam Arvianto juga melaporkan kehilangan tersebut kepada PT Asuransi Ramayana Tbk dalam hal pemenuhan atas hak asuransinya, Namun PT Asuransi Ramayana Tbk menolak klaim yang diajukan Bapak Mery Sam Arvianto karena pada saat terjadi pencurian Bapak Haryono selaku pengemudi tidak memiliki SIM A. Klaim yang diajukan ditolak oleh perusahaan dengan dasar Polis Standard Asuransi Kendaraan Bermotor Indonesia Pasal 3 Angka 4.2 yaitu pada saat terjadi kerugian atau kerusakan, kendaraan bermotor dikemudikan oleh seseorang yang tidak memiliki Surat Izin Mengemudi (SIM) sesuai dengan peraturan perundang-undangan yang berlaku. Atas dasar 
kejadian ini tertanggung merasa dirugikan karena klaim yang diajukan ditolak dan masih berkewajiban membayar angsuran tiap bulannya kepada leasing karena mobil dibeli secara kredit.

Namun demikian, menurut penulis, dasar penolakan klaim oleh PT.Asuransi Ramayana Tbk terhadap klaim yang diajukan Bapak Mery Sam Arvianto tersebut tidak tepat karena peristiwa yang terjadi dalam kasus ini tidak masuk dalam klausula pengecualian, yaitu menolak perihal kehilangan kendaraan bermotor akibat dari tidak cakapnya hukum si sopir/ pengemudi mobil, akan tetapi kasus ini terjadi adalah masalah pencurian kendaraan bermotor, dimana dalam klausula All Risk/ Comprehensive isinya menyatakan jaminan kerusakan sebagian atau keseluruhan mobil karena kejatuhan benda, kebakaran, tabrakan, kecelakaan lalu lintas, pencurian, atau benturan

Polis Standar Asuransi Kendaraan Bermotor Indonesia menjamin (pasal 1):

1.3. pencurian, termasuk pencurian yang didahului atau disertai atau diikuti dengan kekerasan ataupun ancaman kekerasan sebagaimana dimaksud dalam Pasal 362, 363 ayat (3), (4), (5) dan Pasal 365 Kitab Undang-Undang Hukum Pidana;

Sebagaimana disebutkan di atas, risiko yang dijamin adalah "pencurian, termasuk pencurian dengan kekerasan atau ancaman kekerasan" atau singkatnya adalah "pencurian dan perampokan." Terdapat pasal-pasal rujukan dalam KUHP yaitu pasal 362, 363 ayat (3), (4), (5) dan pasal 365

Pencurian adalah "mengambil, sesuatu barang kepunyaan orang lain dengan maksud untuk dimiliki secara melawan hukum" yaitu
Pasal 362 KUHP. Termasuk pencurian yang dijamin dalam Polis Standar Asuransi Kendaraan Bermotor Indonesia adalah pencurian yang dilakukan dengan menyelinap masuk rumah atau pekarangan rumah (Pasal 363 (3)), pencurian yang dilakukan oleh dua orang atau lebih dengan bersekutu (Pasal 363 (4)) dan pencurian yang dilakukan dengan memakai "anak kunci palsu" atau "perintah palsu" (Pasal 363 (5)), sedangkan Perampokan adalah pencurian yang didahului, disertai atau diikuti dengan kekerasan atau ancaman kekerasan terhadap orang (Pasal 365).

Pencurian yang tidak dijamin dalam Polis Standar Asuransi Kendaraan Bermotor Indonesia adalah sebagaimana diatur dalam pasal 363 ayat 2 KUHP yaitu "pencurian pada waktu ada kebakaran, letusan, banjir, gempa bumi, atau gempa laut, gunung meletus, kapal karam, kapal terdampar, kecelakaan kereta api, huru-hara, pemberontakan atau bahaya perang;"

Pencurian yang dilakukan oleh suami atau istri atau anggota keluarga sedarah atau semenda (Pasal 367) tidak dijamin dalam Polis Standar Asuransi Kendaraan Bermotor Indonesia

Penggelapan, penipuan dan hipnotis, Penggelapan adalah dengan sengaja dan melawan hukum memiliki barang kepunyaan orang lain, tetapi yang ada dalam kekuasaanya (Pasal 372 KUHP), Penipuan dan hipnotis adalah sebagaimana diatur dalam Pasal 378 KUHP yaitu pencurian dengan memakai tipu muslihat, ataupun rangkaian kebohongan menggerakkan orang lain untuk menyerahkan barang sesuatu.

Sesuai dengan asas Perjanjian berlaku sebagai undang-undang (Pacta sunt Ser- 
vanda), dalam asas ini suatu perjanjian yang dibuat secara sah mempunyai ikatan hukum yang penuh, yang diatur di dalam Pasal 1338 angka (1) KUH Perdata, yang menyatakan bahwa "Semua perjanjian yang dibuat secara sah berlaku sebagai Undang-undang bagi mereka yang membuatnya".

Penolakan PT. Asuransi Ramayana Tbk atas klaim yang diajukan Bapak Mery Sam Arvianto dengan dasar ketidakcakapan hukum pengemudi karena tidak memiliki SIM A selain tidak tepat juga tidak ada korelasi antara tidak mempunyai SIM dengan kasus pencurian yang terjadi sesuai yang diatur dalam BAB Pasal 1 Polis asuransi kendaraan bermotor Indonesia yang mengatur tentang Jaminan, diantaranya angka 1.3 tentang pencurian. Dalam perjanjian berlaku asas pacta sunt servanda, dimana para pihak disini yang melakukan perjanjian asuransi klausul All Risk/ Comprehensiv adalah antara PT.Asuransi Ramayana Tbk dan Bapak Mery Sam Arvianto sehingga kedua belah pihak terikat pemenuhan atas hak dan kewajiban dalam perjanjian tersebut.

Apabila pihak tertanggung tetap ingin mendapatkan klaim dan belum puas maka kasus klaim asuransi ini akan menjadi permasalahan dan dapat diselesaikan sesuai dengan kesepakatan dengan melalui pihak Majlis Arbitrase Ad Hoc.

Termuat di dalam Polis Standart Asuransi Kendaraan Bermotor bahwa dalam salah satu pasal tentang perselisihan, dimana apabila terjadi perselisihan antara penangOgung dan tertanggung sebagai akibat dari penafsiran atas tanggung jawab atau besarnya ganti rugi dalam polis, maka perselisihan tersebut akan diselesaikan dengan jalan perdamaian atau musyawarah paling lama 60 hari setelah terjadinya perselisihan tersebut. Penyelesaian klaim tersebut harus dilakukan apabila tujuan yang awalnya adalah untuk meminta ganti rugi klaim asuransi berubah menjadi sengketa yang harus diselesaikan lewat Arbitrase, Pengadilan ataupun Badan Mediasi Asuransi Indonesia (BMAI). Penyelesaian klaim dilakukan apabila klaim yang diajukan berubah menjadi sengketa yang harus diselesaikan melalui pengadilan atau arbitrase sesuai kesepakan yang tercantum dalam penjanjian polis.

Apabila cara penyelesaian perselisihan itu tidak dapat diselesaikan dengan jalur perdamaian (non litigasi) maka masih mempunyai upaya non litigasi yang dapat ditempuh dengan segala kelebihan dan kekurangannya. Namun sebenarnya ada upaya lain untuk menyelesaikan sengketa tentang klaim asuransi yaitu dengan adanya Badan Mediasi Asuransi Indonesia (BMAI).

\section{PENUTUP}

\section{Simpulan}

Berdasarkan uraian diatas maka dapat ditarik kesimpulan sebagai berikut : Pertama, Perlindungan hukum tertanggung dalam perjanjian asuransi kendaraan bermotor PT. Asuransi Ramayana Tbk ditinjau dari hukum asuransi secara umum yakni bilamana terjadi evenemen (peristiwa tidak pasti) yang menimbulkan kerugian, maka berdasarkan Polis Standar Asuransi Kendaraan Bermotor Indonesia BAB 1 Pasal 1 dan Pasal 2, tertanggung berhak mendapatkan ganti kerugian diantaranya karena pencurian. Tertanggung apabila terjadi sengketa berhak mendapatkan penyelesaian sengketa melalui 
lembaga mediasi berdasarkan Pasal 54 BAB XI UU No 40/2014 tentang Perasuransian yaitu tentang Perlindungan Pemegang Polis, Tertanggung, atau Peserta.

Kedua, Berlakunya hukum pada pengajuan klaim tertanggung ditolak PT.Asuransi Ramayana Tbk berdasarkan Polis Standar Asuransi Kendaraan Bermotor Indonesia Pasal 3 Angka 4.2 yaitu pada saat terjadi kerugian atau kerusakan, kendaraan bermotor dikemudikan oleh seseorang yang tidak memiliki Surat Izin Mengemudi (SIM) sesuai dengan peraturan perundang-undangan yang berlaku. Adalah tidak tepat dan tidak berkorelasi dengan kasus pencurian yang terjadi sebab dalam kasus yang dialami Mery Sam Arvianto, dalam perjanjian asuransi dengan nomor polis 18.0212.14.001512 maka tertanggung menurut klausula All Risk/ Comprehensive ( jaminan kerusakan sebagian atau keseluruhan mobil karena kejatuhan benda, kebakaran, tabrakan, kecelakaan lalu lintas, pencurian, atau benturan), seharusnya mendapatkan ganti rugi, hal ini berdasarkan BAB 1 Pasal 1 angka 1.3 Polis Standar Asuransi Kendaraan Bermotor Indonesia yang mengatur tentang jaminan, diantaranya tentang pencurian.

\section{Saran}

Pertama, Untuk Perusahaan Asuransi, Perusahaan asuransi sebagai penanggung dengan tegas memberikan kriteria dan batasan luasnya proteksi atau jaminan yang diberikannya kepada tertanggung, dan dicantumkan di dalam polis. Apabila terjadi kerugian yang disebabkan karena peristiwa-peristiwa yang diperjanjikan itulah penanggung membayar ganti kerugian.
Kedua, Untuk Tertanggung. Bilamana pihak tertanggung yang ditolak klaimnya oleh PT Asuransi Ramayana Tbk ingin mendapatkan klaim ataupun belum puas, maka kasus klaim asuransi ini akan menjadi permasalahan dan dapat diselesaikan sesuai dengan kesepakatan dengan melalui pihak Majlis Arbitrase Ad Hoc. Termuat di dalam Polis Standar Asuransi Kendaraan Bermotor bahwa dalam salah satu pasal tentang perselisihan, dimana apabila terjadi perselisihan antara penanggung dan tertanggung sebagai akibat dari penafsiran atas tanggungjawab atau besarnya ganti rugi dalam polis, maka perselisihan tersebut akan diselesaikan dengan jalan perdamaian atau musyawarah paling lama 60 hari setelah terjadinya perselisihan tersebut.

\section{DAFTAR PUSTAKA}

Ernawati, DE. 2009. Penerapan Asas-asas Hukum Asuransi dalam Perjanjian Asuransi Kendaraan Bermotor di PT. Asuransi Raksa Pratikara di Wilayah Surakarta. Tesis Fakultas Hukum, Universitas Diponegoro, Semarang. (Tidak dipublikasikan);

Hadjon, Philipus $\mathrm{M}_{2}$ 1987, Perlindungan Hukum bagi Rakyat Indonesia, Bina IImu, Surabaya;

Hartono, Sri Rejeki, 2001, Hukum Asuransi dan Perusahaan Asuransi, Sinar Grafika, Jakarta;

Marzuki, Peter Mahmud, 2005, Penelitian Hukum, Kencana Perdana Media Group, Surabaya;

Raharjo, Satijipto, 2000, IImu Hukum, PT. Citra Aditya Bakti, Bandung;

Soekanto, Soerjono dan Sri Mamudji. 2004. Penelitian Hukum Normatif, Suatu Tinjauan Singkat. Raja Grafindo Persada. Jakarta;

Sulistyandari, 2012, Hukum Perbankan (Perlindungan Hukum Terhadap Nasabah 
Penyimpan Melalui Pengawasan Perbankan di Indonesia), Laras, Sidoarjo.

Sunggono, Bambang , 2006, Metode Penelitian Hukum, PT Raja Grafindo Persada, Jakarta

Zainudin, 2013. Hukum Pertanggungan atau Asuransi. (On-line), http://muhyusuf0464.blogspot.com/2013/ 11/yu.html diakses 12 Desember 2014 